\title{
Terrorism, Human Rights and Ethics: A Modelling Approach
}

\section{M.A. Hersh}

Professor, University of Glasgow, Glasgow, Scotland

*Corresponding author: M.A. Hersh, Biomedical Engineering, University of Glasgow, Glasgow G12 8 LT, Scotland, Tel: +44 1413304906 ; Email: marion.hersh@glasgow.ac.uk

Rec date: Jan 20, 2016; Acc date: Jan 26, 2016; Pub date: Feb 02, 2016

Copyright: (c) 2016 Hersh. This is an open-access article distributed under the terms of the Creative Commons Attribution License, which permits unrestricted use, distribution, and reproduction in any medium, provided the original author and source are credited.

\begin{abstract}
This paper applies ethical analysis techniques, including multi-loop adaptive learning and virtue ethics, to the analysis of both state and non-state terrorism. It also discusses the use of the fear of terrorism as a control mechanism by the state, the ways in which this fear can be encouraged, including by the media, and used to scapegoat minority groups to divert attention from government policies. A number of feedback models are presented to illustrate the relationships between terrorist acts, fear of terrorism, vested interests and scapegoating.
\end{abstract}

Keywords: Feedback; ethics; terrorism; human rights; modelling

\section{Introduction}

\section{What is 'Terrorism'?}

The aim of this paper is the application of ethical analysis and modelling techniques to improve understanding of the circumstances which encourage or promote terrorism and the ethical issues associated with terrorism and counter-terrorism. The paper is organised as follows: The first two sections of the paper provide the framework for the subsequent ethical analysis through discussion of the various definitions of terrorism and the context for terrorism, as well as the meaning of individual and collective responsibility. The following three sections present a number of different approaches to the ethical analysis of terrorism; consider some of the ethical issues arising in counter-terrorism; and consider the extent of the terrorist threat and the nature of the response to terrorism. Conclusions are presented in the final section.

\section{Definitions of terrorism}

The theoretical analysis requires a definition of terrorism, but 'terrorism' is a political concept and consequently its definition is not uncontroversial. Etymologically terrorism is derived from the Latin verb terrere, to frighten and the term was probably first used in its French form 'terrorisme' to describe the use of the arrest or execution of opponents by the Jacobin club in post-revolutionary France to terrorise the general public into compliance [1].

Common elements of a number of definitions include [1-4] the use of violence, intimidation or the threat of violence against a person or a (large) group in order to achieve political, ideological, social or religious goals by putting pressure on or intimidating another group of people or another individual to carry out actions they would otherwise be opposed to. Therefore the people to be influenced are generally different from those who experience the violence, though they may be members of the same group. Thus, for instance, terrorist violence could be directed against civilians to put pressure on a government or against a particular government minister to put pressure on other government ministers. Some definitions include acts carried out by agents on behalf of other people and acts which may aim to provoke extreme counter measures to win public support for the terrorists. It should also be noted that terrorism is not a new phenonomen [2].

The term violence itself has a number of definitions. For instance Coady [5] presents three definitions, 'wide' and 'legitimate' definitions generally relating to left and right wing political philosophies and including social injustices and the illegal employment of methods of physical coercion for individual or group ends' respectively. It should be noted that these two approaches respectively question and support the status quo. Coady's 'restricted' definition relates mainly to the infliction of physical harm [5], and therefore excludes verbal violence and mental cruelty. Coady also makes a useful distinction between harm to oneself or others caused directly by actions and harm resulting from omissions, which he labels positive and negative violence respectively. This will be touched on later in the discussion of collective responsibility resulting from omissions. In the subsequent discussion the expression 'terrorist' will be used as short-hand for people who have been involved in organising, planning or carrying out terrorist acts.

There is disagreement as to whether terrorism only includes violence (or the threat of it) directed against civilians and/or innocent people with 'innocent' defined with regard to the activity or issue of concern to the 'terrorists', whether the violence may be directed against property and whether or not terrorism includes acts of violence by governments in power or acts of violence in war. The Global Terrorism Database includes incidents involving 'an intentional act of violence or threat of violence by a non-state actor' [6]. It excludes 'state terrorism, but includes property damage as well as violence against people. It has been suggested that the (short term) aims of terrorism are to publicize and draw attention to issues in the sense of a violent demonstration, rather than to achieve change, and to damage policies and economies [7] and that, while each terrorist group has different primary motives, common secondary motives are revenge, renown (glory as well as publicity) and reaction [8]. In addition, terrorism may include other aims, such as punishment, calling attention to problems or expressing frustration, in addition to coercion [9]. Analogously to non-violent demonstrations, terrorist acts are more likely to achieve change as part of a concerted campaign, rather than as isolated acts. 
War crimes, government repression or disappearance of civilians and genocide are generally excluded from definitions of terrorism. However, distinctions have been made between 'state' and 'oppositional' terrorism [10], with the focus generally on oppositional terrorism. Even when governments are excluded as terrorists, statesponsored terrorism in which governments support terrorism in another state is recognized. 'Organised crime' is generally excluded from definitions of terrorism, even when it involves violence and intimidation. However there may be arguments for labelling acts of intimidation aimed at extorting 'protection' money and giving a 'crime lord' control of a particular area as terrorist. It has been suggested that state terrorism is morally worse than terrorism by non-state actors. In particular, the scale of death, injury and general destruction is many times greater in state than non-state terrorism. State terrorism is frequently accompanied by deception of the public, a hypocritical condemnation of terrorism and the commission of acts prohibited by human rights declarations to which most governments, but not nonstate bodies, are signatories [11]. The term state terror is sometimes used to describe the actions of official organizations such as the Gestapo, the KGB and the Stasi against dissidents or ethnic minorities. One of the main differences between terrorism by states and other actors is that states generally use terrorism to oppose changes to the status quo, whereas non-state actors use terrorism to try to change the status quo [12]. Government definitions of terrorism tend to be slanted to include their enemies, but not their irregular allies or friends $[13,14]$, with actions by the latter considered a 'justified response' or justified self-defence' [15].

In addition it has been suggested that use of the term terrorist is solely about propaganda and prevents examination of the causes and consequences of the political situation which has given rise to terrorist acts [16]. Thus definitions of terrorism have a political and ideological nature, with care being taken to differentiate acts by governments from those carried out by other (terrorist) individuals and organizations. This allows, for instance, the bombing of London and Dresden, the US bombings in the Vietnam war and the nuclear bombing of Hiroshima and Nagasaki not to be labelled as terrorist, although they involved the targeting of civilians with the aim of spreading fear and demoralisation [15].

Terrorism has been linked to non-territorial violence and civil war to territorial conflict [17]. However, it has also been recognised that this correspondence is not absolute. For instance, the Taliban in Afghanistan is considered a terrorist organisation despite controlling territory [6].

\section{The prevalence of terrorism}

On the one hand the number of deaths from terrorism has increased nearly ten-fold from 3,361 in 2000 to 32,685 in 2014 and the rate of increase may be growing with a $61 \%$ increase from 2012 to 2013 and an $80 \%$ increase from 2013 to $2014[6,18]$. On the other, the scale of deaths is still only a fraction (7.5\%) of the over 437,000 killed by homicides each year. The estimated economic costs of terrorism (US $\$ 52.9$ billion in 2014) are still only about 3\% of the economic costs of violent crime and homicides. $78 \%$ of the 'terrorist' deaths in 2014 and over $80 \%$ of those in 2013 occurred in only five countries, Iraq, Nigeria, Afghanistan, Pakistan and Syria, mainly in the context of ongoing violent conflict. Terrorism is generally linked to other forms of violence. $92 \%$ of terrorist attacks in the period 1989-2014 have been found to occur in countries with widespread governmental political violence and $88 \%$ of terrorist attacks in the period 1985-2014 took place in countries with violent conflicts [6]. The significant growth of terrorism from 2013 or 2014 may be due to relatively high levels of violence in that year and a greater number of wars than in any year since 2000 [19]. Countries without ongoing conflict or political terror experience only $0.6 \%$ of terrorist attacks [6]. The relationship between violent conflict and terrorism and state and non-state terror indicate that it may be appropriate to classify terrorism as a form of violent conflict, rather than separately, and to analyze state and non-state terror in parallel.

Despite the concentration of terrorist attacks and deaths in a small number of countries, the number of countries experiencing terrorist incidents is growing, with attacks taking place in 93 countries in 2014 and eleven countries having more than 500 deaths, though the majority of countries in the world did not have terrorism related deaths. Only a minority of terrorist attacks occur in the west, with only $0.5 \%$ of terrorism deaths over the last 15 years excluding the September 11 deaths taking place in the USA, Canada, Australia and Europe and $2.6 \%$ if they are included. Most of the terrorist attacks in the west were carried out by individuals and $80 \%$ of deaths over the nine years to 2014 were motivated by right wing extremism, nationalism, political extremism and anti-government feelings not Islamic fundamentalism [6].

\section{Context and Causes of Terrorism}

However it may appear to outsiders, the behaviour of 'terrorists' is generally self-consistent and rational [8]. It is therefore useful to consider the factors which increase the likelihood of the commission of terrorist acts. The theories of the reasons or causes for terrorism include the following $[1,4,10]$ :

- Sociological explanations, focusing on the societal position of the perpetrators.

- Psychological explanations of why particular individuals join terrorist organizations.

- Conflict theory explanations based on an examination of the relationship between the perpetrators and those in power.

- Ideological explanations based on different goals and/or ideologies.

- Media theory explanations, with terrorism understood as a form of communication.

- Poverty and in-country economic inequality.

- Socio-economic and/or political transformation and instability.

- Clashes of identity and/or culture.

Discussion of the causes of terrorism [20] has often focused on whether international terrorism results from causes which are internal or external to the state. Internal factors include personal, societal, cultural and governmental variables. External factors include the foreign policies of other states, trends in the global diffusion of military capabilities, the expansion of telecommunications and the unequal distribution of wealth and influence. In practice both internal and external factors may contribute, but it can be useful to investigate the comparative importance of the different types of factors. There are also further distinctions [20], between theories that the underlying causes of terrorism are based in inequality and oppression, including poverty, colonialism, ethnic separation and persecution, and theories that terrorism is an unprincipled decision to wage a campaign of violence outside the accepted rules of warfare. It has also been suggested that terrorist activities are carried out by people without power and driven largely by material and financial assistance and propaganda support by 
Page 3 of 13

government sponsors. Some, but by no means all terrorist organisations receive support from external states and some terrorist organisations would find it difficult to survive without this support. A number of governments of varying political complexions have provided support to 'terrorist' organisations. However, this does not justify the labelling of certain states as 'terrorist' and even less does the use of this label provide a justification for war against these states.

The main factors that have been shown to be significantly correlated with terrorism can be grouped into the following three factors [6]:

- Hostility between different ethnic, religious and linguistic groups, including lack of intergroup cohesion, social hostility, group grievances, religious tensions, sectarian, communal or mob violence and religious tensions.

- State-sponsored violence, including extrajudicial killings, political terror, deaths in conflict, lack of physical integrity rights and ongoing conflict.

- Other forms of violence, including guerilla acts, force or coercion by organised groups and violent crime.

Poverty has frequently been linked to terrorism by policy makers, but the evidence is inconclusive. However, it has been shown that economic discrimination of minority groups increases the likelihood and number of incidents of domestic terrorism [21]. A concave relationship has been found between economic development and no territorial conflicts [17]. (Non-state) terrorism has been found to be more prevalent in democracies, at least for the period 1975-1997While it has been suggested that this is due to intergroup competition promoted by political competition [22], another possible explanation is that a certain appearance of freedom is necessary for terrorism to have an impact. In very repressive states the impacts of terrorist activity by non-state groups may be insignificant compared to the degree of fear associated with state terrorism. However, as indicated above, a link has been found between state and non-state terrorism. In addition, the fact that the majority of terrorist incidents are now occurring in five not particularly democratic countries indicates that there is no longer a link between terrorism and democracy. There is some, though not yet strong statistical evidence for humiliation (possibly linked to gender roles) being a factor [15] and there may also be a link between economic discrimination and humiliation. Although there is some evidence of the increasing participation of women in terrorism [23], it is still largely a male activity [24]. However, there seems to be limited research on the construction of gender roles, particularly masculinity, and the role of the particular construction and expectations of masculinity in a given context and the interactions of this constructed masculinity with economic discrimination, humiliation and other factors in leading to terrorism and/or the participation of individuals in it.

Other contextual factors which may contribute to terrorism, but where more evidence is required include the following:

- Lack of success or a slow or insufficient response to other methods and desperation due to the (perceived) importance of the issue.

- Marginalisation, discrimination and social exclusion, including from decision making structures and access to decision makers.

- The removal of rights, dehumanization or even demonization of certain groups, which then justifies any type of abuse or alternatively their instrumentalization, making their needs and rights subordinate to those of other social groups.

- External or internal vested interests which actively oppose peaceful change which would reduce their own power and influence and which may contribute resources and funding to terrorist organizations.

However, even in countries with high levels of terrorist incidents, they occur as either separate individual or separate groups of incidents. This suggests the need for a trigger event for terrorist act(s) to actually occur. The reaction to these terrorist acts will depend on a number of factors, including the political regime, and vested interests.

This reaction will feed back and could act as a trigger event or moderate the effect of other trigger events. This is illustrated in Figure 1

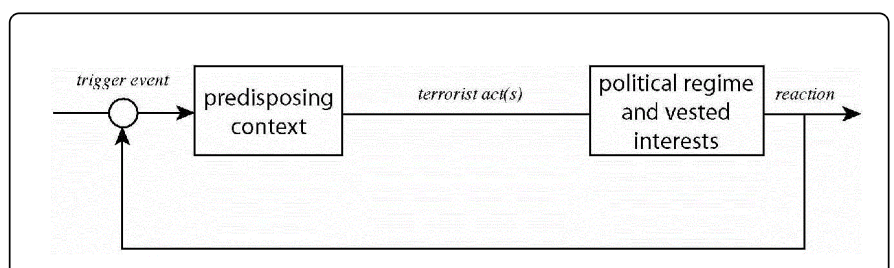

Figure 1: Terrorism and its responses

The factors presented above can be seen to have been similarities with those that lead to violence, as described by the author's threecomponent model of conflict [25]. Thus, this model can be generalised to give the three component model, shown in figure 2, of the causes of terrorist acts:

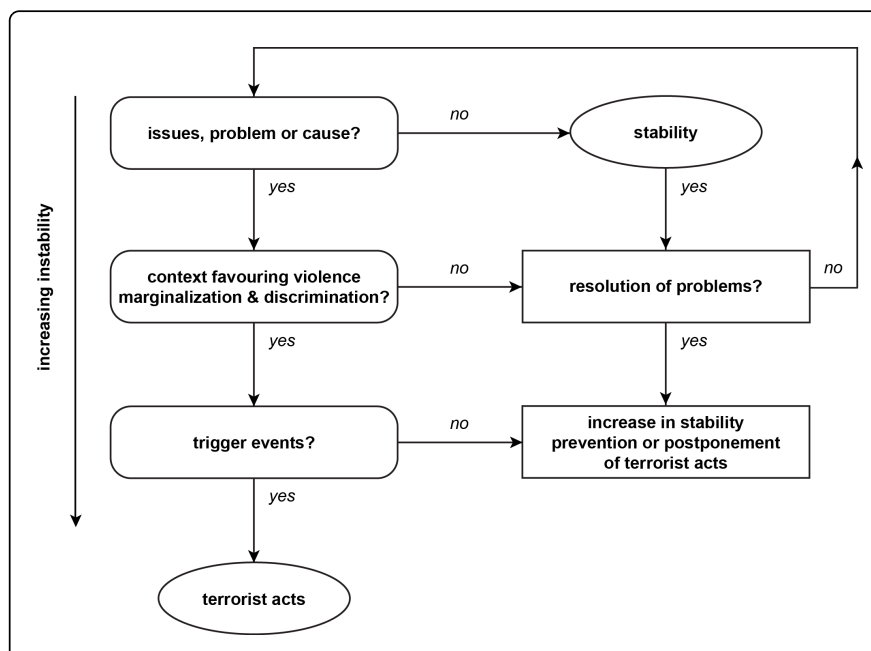

Figure 2: Three-component model of the causes of terrorist acts

- Issue: This includes problems and causes which may be political, ideological, religious or other.

- Context: A context which is characterized by violent conflict, hostility between different groups, state sponsored violence and violation of physical integrity rights and other forms of violence.

- Trigger: Trigger event(s) or circumstance(s), such as a massacre or the introduction of further repressive legislation, which exacerbates the situation and make the possibility of positive change leading to resolution of the problems or advance of the cause increasingly unlikely.

This model is useful in depicting the factors which lead to the commission of terrorist acts. The first two factors depict an unstable 
situation which has the potential to lead to the commission of terrorist acts and the third factor the 'spark' or 'final straw'. The model also makes the link between terrorist acts and other forms of violence, including war.

\section{Individual and collective responsibility}

Definitions of terrorism generally define innocence in terms of a lack of involvement with the issue of concern. However, there are also issues of individual and collective responsibility. In some cases terrorists may hold groups within a state or even all citizens collectively responsible for injustices, though punishment is generally not the motivation for terrorism. However, defence against an oppressive state may require attacks on some of its members, even if they have no responsibility for the state's oppression [26]. A distinction can also be made between distributive and non-distributive collective responsibility. Distributive responsibility results in individual responsibility for the consequences of decisions, whereas nondistributive responsibility does not. For instance, members of a government or a town council share distributive responsibility for the consequences of the decisions it makes, whereas citizens of the country or town have non-distributive responsibility. It is also sometimes claimed that citizens are responsible as a result of things they have not done, for instance by failing to oppose the injustices or try to rectify them. There are also issues as to whether or not ordinary citizens benefit from particular injustices [26].

The issue of individual responsibility through not acting to oppose injustice or at least speaking out against it is particularly interesting. I would suggest that we all share collective responsibility for what happens both locally and in the rest of the world and that this gives us an individual responsibility to oppose injustice and to try to achieve positive change. The best ways of fulfilling this responsibility in practice depend on a number of factors, including our own circumstances and the degree of risk. However, if we do not at least speak out about injustices carried out by our governments in our name and from which we may derive benefit, then it does not seem unreasonable to hold us at least partially responsible for them. This leads to the questions of whether collective responsibility is the same as collective guilt and whether it is morally justifiable to punish people who can be recognized to have collective responsibility solely as the result of not having done anything to prevent injustices.

\section{Ethical Analysis}

In this and subsequent sections a number of different approaches, based largely on some of the different theories of ethics [27] are applied to investigate the contexts in which terrorism might be justified, as well as the circumstances which lead to it. Where appropriate, issues relevant to counter-terrorism will be considered in this section, with a more extensive discussion in the following section. The ethical questions of interest which will be discussed include the following:

- Ethical issues related to the commission of terrorist acts, including whether they are ever ethically permissible and, if so, in what circumstances.

- Ethical issues involved in counter-terrorism activities, including whether it is justified to suspend human rights in the fight against terrorism and if so, in which circumstances and which rights.
- Contextual issues related to the resources and attention given to fighting terrorism and other threats, many of which actually or potentially result in much higher numbers of deaths and injuries.

It has been suggested that 'terrorist attacks by the groups victimized by the Nazis, for example, would hardly have deserved any negative evaluations.' [13]. However, this needs further investigation. If the premise is accepted, it still raises questions of the types of terrorist acts that would have been ethically permissible. For instance, would it have been justified for these groups to carry out attacks on the children of prominent Nazis, assuming this would have been feasible in practice?

However, the issue is much wider than terrorism on its own and relates to whether it is ever justified to use violence and, if so, in what circumstances. Moral positions should preferably be coherent and consistent. Therefore, the labelling of particular acts as 'terrorist' rather than, for instance, 'warfare' should not affect ethical judgments about them. Discussions about the circumstances in which the use of violence might be justified are part of the wider argument of the relationship between ends and means or consequentialist and deontological ethics. It has been suggested that the use of political violence cannot be justified unless all channels of non-violent protest have been exhausted [28]. While it is clearly desirable to use nonviolent means if at all possible, this argument is problematic, since it is not always clear what channels of non-violent protest are available and the need for change may be urgent due to the existing state of violence and oppression. In addition, engaging in non-violent protest may itself put participants at risk and could lead to reprisals and repression. However, on the other side of the argument, there is no guarantee that political violence will be successful in achieving its aims or even that it has a greater likelihood of success than non-violent means. In addition, non-violent resistance has the potential to involve a much greater proportion of the population and to empower them. There is also sometimes a relationship between the ends achieved and the means used. Thus, the use of peaceful means has the potential to achieve change at a deeper level and which is longer lasting, whereas change achieved by violence may require a further peaceful 'revolution' to remove the violence that has become embedded.

Several different authors have suggested conditions under which the use of political violence or terrorism might be justified. These include [2] the use of terrorism by a morally innocent individual (however moral innocence is defined) to defend themselves or other morally innocent people against a significant injustice using terrorist activities which are directed proportionately and only against those guilty of committing acts of significant injustice. Further conditions include replicability i.e. moral justification of the use of terrorism by others in similar circumstances, planning for the use of terrorism to achieve the cessation of the injustice and, previous attempts to use non-violent means, if this is feasible. Further suggestions include the justification of the use of political violence [12] to prevent immediate injury or longer range threats to oneself or others and to prevent or rectify the loss of legitimate liberty by oneself or others. However, it has also been suggested that the use of political violence is probably not justified to obtain conditions of a minimally acceptable life even when there are no other means available to do this and that it is also not justified to promote a better life for oneself, a particular group or people in general. I would disagree with the contention expressed by Narveson [12] and others that there is not a fundamental right to an (approximately) equal share of the world's natural resources and socially produced goods. The logical conclusion of not accepting this as a fundamental right is accepting an unequal distribution, with some 
individuals and groups having significantly reduced and probably inadequate shares of these resources and goods.

While the difference in perspective is largely based on a difference in political philosophy or ideology, an unequal division of the world's resources and goods is also counter to many ethical theories [27], implying that access to equal shares is a fundamental right in ethical terms. In terms of deontological ethics making significant differences in the shares received by different individuals or groups is not innately virtuous and is unlikely to be based on good intentions. With regard to positive utilarianism the benefits of an unequal distribution are likely to be low and the costs high. In terms of negative utilarianism there are likely to be significant present and future harms due to many people receiving insufficient for their needs. With regard to virtue ethics an unequal distribution is unlikely to build good character either of those who receive less or those who receive more than an equal share. In terms of normative ethics there is an inherent injustice in an unequal distribution, it is unlikely to promote autonomy and is malificent rather than beneficent. Since unequal distributions frequently lead to feelings of resentment, the result is unlikely to promote relationships and is therefore counter to the ethics of care. Differences in beliefs about the fundamental entitlement to an equal share of the world's resources will affect any analysis of the ethical justification for using terrorism to access basic needs or a fair share of the world's resources, assuming no other means are available to do this. However, acceptance that everyone is entitled to (approximately) equal shares of the world's resources does not imply that the use of terrorism is ethically permissible and this would have to be further evaluated through application of ethical theories.

\section{Consequentialist approaches}

The ethical analysis of terrorism has most frequently used utilarian and, in particular, consequentialist ethics and involved an overall assessment of the likely benefits and harms. Whether or not there are circumstances in which terrorism can be justified is clearly controversial and there are opinions on both sides. Consequentialist arguments have been made both for and against terrorism e.g. [2, 29] based on whether or not terrorism results in an increase or decrease of good in society. It has been argued that terrorism is always morally unjustified, as it uses terror, is coercive, infringes rights and harms the innocent [30]. This has been countered by the suggestion that harming or threatening to harm others and producing feelings of terror are insufficient to make it morally unjustified, as punishing wrongdoers includes a degree of harm and, for instance, civil disobedience and non-violent direct action against racial segregation in the southern USA made many segregationists very afraid, but were morally justified due to the evil inherent in segregation [2]. However, unlike civil disobedience and non-violent direct action, terrorism may lead to actual harm and even death, not just feelings of fear. There has also frequently been considerable inconsistency between attitudes to 'terrorism' and war, both of which harm or threaten to harm others, at least purportedly in pursuit of a greater good. Examples include the Iraq war carried out, under a number of different pretexts including regime change and removing weapons of mass destruction. It resulted in between 151,000 and 655,000 violent deaths in the first three years of the conflict, the displacement of over three million people as refugees or internally, disruption of basic services, health deterioration and unemployment of about 28\% [31]. However, no evidence of weapons of mass destruction was found, the USA which led the invasion continues to be the possessor of the most nuclear weapons in the world [32] and the misrepresentation of pre-war intelligence has been strongly criticized in the USA and internationally [33]. In addition, the Iraq war has played a major role in leading to the current state of unrest and increase in terrorist attacks in Iraq and Syria.

According to consequentialist ethics, terrorist acts are justifiable if they lead to better consequences than the alternatives. The historical evidence is difficult to interpret with opinions both that terrorist violence generally results in violent repression and acts counter to political progress [34] and that it has often contributed to progressive developments [35]. It is generally very difficult to predict the impact of a terrorist acts or series of acts and whether they will contribute to or impede the achievement of progressive goals and the ending of human rights violations. It it is common to undertake acts with uncertain outcomes [9]. However, there is a difference between acts with uncertain outcomes which, as far as can be determined, are unlikely to lead to death and injury and terrorist and other violent incidents which are intended to cause at the least fear and probably also death and injury. However, the existing situation may also be characterized by extreme violence, which is highly likely to continue unless action is taken to end it [9]. A particular issue is raised by the oppression of minority groups by majority groups [2]. However, there is no guarantee that terrorism will end oppression and injustice or that it is more likely to do this than more peaceful means. Consequentalist ethics involves consideration of the overall balance of benefits and harms, including the relative value given to them. There will also neecd to be a way of taking into account uncertainties. As in the case of definitions of terrorism, an inconsistency in the utilarian evaluation of terrorist acts which injure non-combatants has been noted, with those carried out by one's own or friendly states generally considered acceptable and those carried out by unfriendly states unacceptable [5].

\section{Just war theory}

Just war theory $[36,37]$ has two categories, which consider the justification for going to war and the ways in which the war is waged respectively. However, it should be noted that, although just war theory aims to restrict the occurrences of war and eliminate the worst atrocities and provides reasons for forbidding violence, war, terror and counter-terror [38], the process of regulating war and giving it rules also contributes to legitimating war and making it acceptable. The problematical features of applying just war theory to terrorism include the requirement for a correct decision authority and an open declaration of war [37]. Since state terrorism is excluded from many of the definitions, terrorist acts are unlikely to be commanded by a 'correct decision authority'. Terrorist acts are often carried out by groups without national self-determination. However, their nonrecognition by other national governments and consequent classification as criminals rather than enemy forces is often based on self-interest. This raises the issue of whether and in what circumstances national governments should recognize more credible representatives of the people than an unpopular and abusive government [39]. It is also possible that recognition and access to the decision making process would lead to some terrorist organizations withdrawing from terrorism.

There are two main principles [40] for the conduct of a just war:

- The principle of discrimination, which restricts the types of weapons and methods that can be used and the targets that can be considered legitimate. Uninvolved outsiders and large scale 'collateral damage' are specifically excluded. 
- The principle of proportionality, which limits the degree of response in terms of the costs of the resulting damage and the benefits of achieving the war aims.

The principle of double effect can be applied to permit harm to noncombatants in some circumstances in a 'just' war. However, it is not universally accepted and is open to abuse, particularly through ignoring the principle of proportionality [40]. It has been estimated that war and conflict related casualties have changed from $90 \%$ soldiers at the start of the twentieth century [41] to $75 \%$ civilians, many of them children [42] due to a combination of the direct targeting of civilians and 'collateral damage'. The term collateral damage is itself problematical and indicates the treatment of the potential victims as purely a means to an end, contrary to the Kantian requirement that individuals should be treated as an end in themselves [43]. The fact that the overwhelming majority of casualties in war are now civilians indicates that, regardless of other factors, modern war can no longer be considered 'just'.

Just war theory depends at least in part on the drawing of boundaries, including those between (i) people who can legitimately be killed and those who cannot; (ii) circumstances in which this killing is and is not legitimate; and (iii) intended as opposed to merely foreseen killing. This raises the issue of who makes someone a member of a military force rather than a murderer or terrorist and what gives political leaders and military organizations the right to give out licenses to kill. It has been suggested that the 'authorities of a nation state' do not automatically have this right. Analogously to the claims by most armies that their war is a just war, 'terrorists' can equally claim that their violence is justified. The categories of 'innocent', 'soldier' and 'declared war' are based on a mutually accepted authority structure from which the organizations and individuals who commit terrorist acts are excluded [7].

On the other hand it has been suggested that the principle of noncombatant immunity prohibits killing or severely injuring noncombatants, except possibly when weak forces are fighting unjust oppression e.g. [44]. However, this distinction has been questioned [9] In particular, there are about 300,000 child soldiers worldwide and children under 15 participated in armed conflicts in 27 countries in 1997-8. About 20 countries, including the USA and UK, recruit children under 18. The majority of child soldiers are adolescents, though some countries recruit or force children as young as seven into military duty [45]. Many of these children and young people, including in the richer countries, are from poor families with few options [15]. Others are forcibly rounded up. In addition, the extent of real choice in either joining the military or 'seeking to endanger others' [44] exercised by even adult soldiers is often limited due to being conscripts and/or having few options due to poverty [15]. However, it should also be noted that even in the context of human rights violations, terrorism may not be motivated by or intended to try and rectify these violations.

In addition, developments in weapons technology, amongst other factors, have led to the spread of conflicts and resulted in the de factor removal of this distinction with a change from 90\% 'combatant' casualties [41] to $75 \%$ civilian casualties, many of them children [42]. In addition, nuclear and other weapons of mass destruction are likely to be used indiscriminately and the uses of nuclear weapons in Hiroshima and Nagasaki involved the targeting of civilians [15]. The indiscriminate nature of nuclear weapons means that their use is totally incompatible with a 'just' war.
Thus, there are issues of both the moral distinction between combatants and non-combatants, particularly when the combatants include children and young people who have been forcibly conscripted or joined up due to poverty, and the feasibility of applying this distinction in practice, since the overwhelming majority of casualties are now non-combatants [42]. However, this does not necessarily mean that the distinction between combatants and non-combatants should be eliminated [9]. On the one hand maintaining the distinction between combatants and non-combatants could significantly contribute to preventing the spread of war and reduce the resulting death and injury. However, for this to work, there would need to be a change in the way war is waged to take real measures to ensure that civilians are not killed in combat. On the other hand this distinction creates a group of people, namely combatants, who apparently have a reduced right to life, since they can be legitimately killed in some circumstances. At the same time they also have a licence to kill, if certain conditions are met.

\section{Rights ethics and intervening actions}

Rights ethics is based on consideration of fundamental moral rights, with actions which violate these rights considered to be wrong. Both terrorism and counter-terrorism raise issues of whether it is morally justified to kill, injure or torture one or a relatively smaller number of people in order to save a larger number of other people. The issues related to counter-terrorism will be discussed in a later section. In the case of terrorism, the existing situation is generally categorized by frequent serious violations of human rights, hostility between different groups, state sponsored violence and other forms of violence. Thus, applying rights ethics to the analysis of terrorism leads to an evaluation of the relative importance of different rights and decisions about which rights and whose rights it is least unjustifiable to violate [9]. Wherever possible it is clearly preferable to use non-violent methods to ensure respect for human rights. However, situations where this has been tried without success or non-violent approaches seem unlikely to be successful, give rise to the ethical questions of whether any rights violations are permissible in the short term in order to end human rights violations on a long term basis and, if so, what rights. There is also the practical question with ethical consequences of the likelihood of success. Where success is unlikely or its probability is not sufficiently high (however that is judged) violation of rights of any type to achieve change should not be considered from either an ethical or practical perspective.

Although all rights are important, broad categories of rights of different degrees of importance can be defined. In general, respect for the more important rights should be prioritized and care taken to avoid the violation of important rights in order to achieve respect for less important rights [9]. This implies that terrorism in support of the right to personal security or sufficient access to resources to meet basic needs is more likely to be justified than terrorism in support of less important goals.

\section{Virtue ethics and the ethics of care}

Virtue ethics supports actions which build good character and involves a feedback relationship between conduct and the development of 'virtuous' character [46]. It is based on the premise that a person with moral virtues is more likely to behave ethically than someone who purely follows rules. Virtue ethics assumes that the main ethical question concerns desirable character and recognizes that conduct has an effect on the person. This gives a feedback system, as illustrated in 
Page 7 of 13

Figure 3, in which ethical conduct has an effect on character and the development of virtues and these virtues lead to further ethical behaviour. Virtue ethics is also consistent with spiritually motivated approaches to ethics, since it could be considered to encourage personal and spiritual development through ethical behaviour. However even 'virtuous' people sometimes make mistakes or do things they regret. Virtue ethics is also consistent with an understanding that the means used may shape the ends obtained.

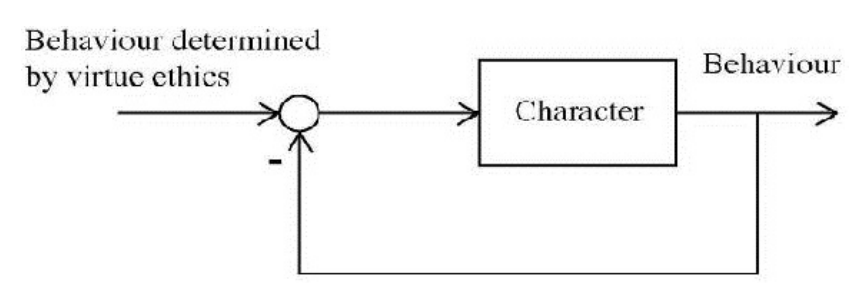

Figure 3: Ehical Behaviour and virtuous character

The application of virtue ethics in the context of terrorism poses interesting questions, as 'terrorists' are often labelled as bad and indeed inhuman people. However, care should be taken to avoid labelling individuals and the associated othering and even dehumanization [25]. It can probably be accepted that the use of violence for whatever reasons has psychologically and psychically damaging effects, regardless of the nature of these reasons. However, the surrounding circumstances and the reasons for the use of violence are also likely to contribute to the effects on character. Therefore, the use of terrorism or other forms of violence is unlikely to have a positive effect on character. However, an idealistic motivation to overcome oppression and disadvantage and do so with minimum suffering to those affected by terrorist acts could lead to a more positive impact. There then remains the question of whether and, if so, how frequently and to what extent real terrorists have this type of motivation and approach.

The ethics of care is a context based approach to preserving relationships [27]. Terrorism clearly has a significant impact on a number of relationships. It is often carried out by people who are powerless to challenge power relationships. This occurs both at the macro level of wider political and economic relationships and at the micro level of, for instance, particular groups of oppressors and oppressed, who are transformed into victims and terrorists. It also has an impact on many other relationships, including within families and communities. The nature of the effects on relationships in the communities terrorists come from will depend on a number of factors, including the community's attitude to the issues they are taking action on, the type of violence used and its targets. Where there are strong feelings of humiliation [15] and or awareness of wrongs for which revenge is required [8] the impact on community relationships is likely to be positive. Relationships with the communities targeted by terrorism may already be so poor that terrorist acts will make little difference. The ethics of care [27] requires moral attention to the situation in all its complexity, sympathizing and even identifying with other people in the situation and accommodation to everyone's needs. Situations which lead to terrorist incidents or other forms of violence are generally characterized by a breakdown of care and relationships across, but not necessarily within communities [6].

They are likely to be characterized by a focus on some aspects of the situation, but ignoring its full complexity, sympathizing and empathizing with some groups and individuals, but a total lack of awareness of the needs of others. There might be value in research on how approaches based on the ethics of care could be used to try and rectify the situation.

\section{Multi-loop action learning}

Multi-loop action learning can be used to investigate the barriers to ethical action and persuading individuals and organisations of the value of such action. It involves the addition of quadruple loop action learning [47] to existing approaches [48] and is illustrated in Figure 4. Single loop action learning is about changing behaviour, rather than learning about ethics and changing values, whereas double loop action learning involves changes in values (generally of individuals) as well as behaviour [48]. Triple and quadruple loop action learning involve changes in the underlying tradition or ethos of the organisation and surrounding society respectively, as well as changes in values and behaviour [47].

As the model illustrates, actions by individuals result from decisions motivated by their values and these values are situated in a context of organizational and societal values. Therefore changing these individual values will generally also require changes in the social context and institutional and wider societal values. As indicated in the section on the causes and context of terrorism, the context in which terrorism takes place is marked by the following $[6,8,15]$ :

- Hostility between different ethnic, religious and linguistic groups,

- State-sponsored violence, including deaths in conflict.

- Other forms of violence, including guerilla acts, force or coercion by organised groups and violent crime.

- Humiliation and the need for revenge.

- Economic discrimination of minority groups.

These factors contribute to the ethos of the wider society in which terrorist and counter-terrorist acts take place. Since even groups which are trying to achieve significant change are part of the wider society, both potentially terrorist and counter-terrorist organizations are almost certain to be influenced by this ethos. The surrounding conflict, other forms of violence, hostility between different groups and economic discrimination of minorities can make it easier to instrumentalize or even dehumanize other people. In the case of terrorism this instrumentalization is directed particularly at those considered to blame for the situation or complicit or guilty by reason of benefiting from or not speaking out against it. In the case of counterterrorism this context is conducive to instrumentalizing and dehumanizing those suspected of being involved in terrorist incidents or likely to do so in the future. It then makes it easy to forget the inconsistencies in purporting to defend civilization against the evil of terrorism [13] by violating the rights of other people and results in an organization or local Social Context with the potential to commit terrorist acts or acts which violate human rights in the service of counter-terrorism.

Individuals are influenced by both the wider society and their immediate Social context. Due to social sanctions and the need experienced by most people to belong and to be accepted it is often very difficult to espouse values or behave in a way that is counter to the ethos of the organization or the local Social context. However, taking action which violates human rights in the service of counter-terrorism requires active participation not just passive acquiescence. In addition, pressures to conform do not excuse individuals from moral responsibility for their acts or make it impossible for them to behave in 
Page 8 of 13

a way that is counter to the ethos of the organization or local social context. It does however make it more difficult to do so and often the price for standing against the organization can be high, as discussed in Hersh [49] in the context of whistleblowing. The forward link from the wider Social context to the individual has been discussed. However, as indicated in Figure 4 there are also feedback links from the individual to the organization and wider society. This indicates that individuals are able to influence the organization and wider society. However, doing so collectively as part of an organization both increases effectiveness and reduces the likelihood of victimization.

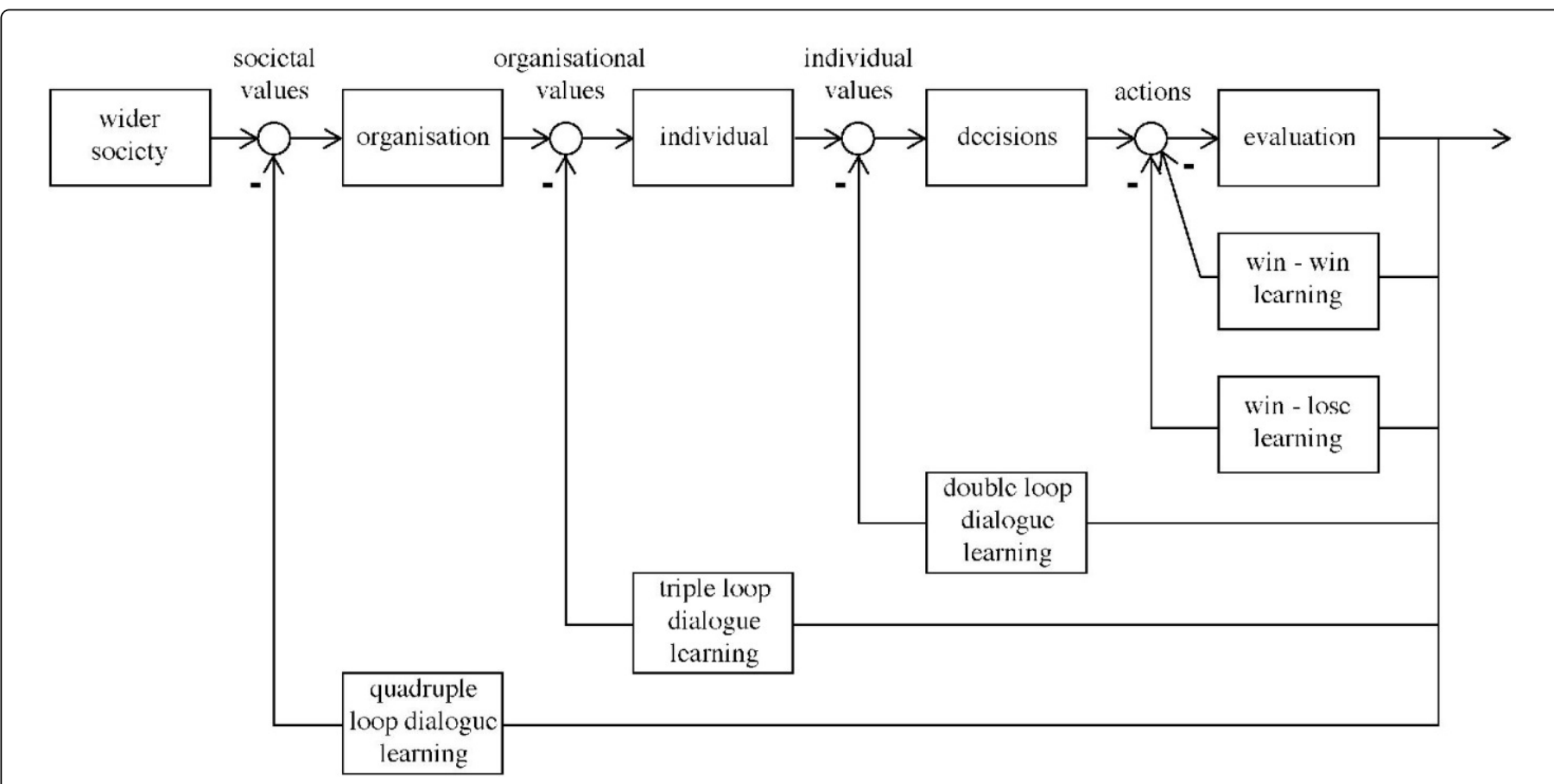

Figure 4: Multi-loop action learning

\section{The Ethics of Counter Terrorism}

Counter-terrorism may involve a number of activities of questionable ethics, including assassination/killing, lethal drone strikes, torture, data screening, high tech surveillance and the imposition of legislation which restricts civil liberties and human rights, frequently on a discriminatory basis [50-52]. According to both rights ethics and international law people have a number of basic rights, some of which are inalienable and unconditional, whereas others are considered to be conditional. There is some dispute as to whether the right to life is totally inviolable and inalienable or whether it can be lost in some circumstances [53]. A position of total inalienability of the right to life would prohibit physical violence that could lead to death, except possibly in the case of self-defence where the rights to life of the attacker(s) and victim(s) are in conflict. The suggestion that the right to life can be overridden by the claims of criminal justice after due legal process [53] is problematical for a number of reasons. In particular, a person who has been detained is no longer a threat to other people's rights to life. It is also very rarely possible to force members of state governments that have been responsible for extrajudicial executions, disappearances and other violations of human rights to participate in a due legal process. The pre-emptive assassination of suspected potential terrorists, is generally based purely on suspicion rather than conclusive evidence that the suspects will kill or injure other people. Decisions about pre-emptive assumptions may be motivated by a political agenda which leads to the labelling of members of particular ethnic or religious groups as potential terrorists and which could lead to assassination on this basis.
However, it should also be noted that, despite the ethical and legal dubiety of the pre-emptive assassination of potential terrorist murderers, it is still a lesser evil than either the invasion of countries suspected of harbouring terrorist organisations or the use of the rumoured presence of terrorist organisations as a pretext for invasion.

While drastic action may be believed necessary to avert a potential and serious terrorist threat, the principle of intervening action does not morally required the execution of one person in order to save others, as it is the intervening action of another person which leads to these deaths [36]. However, a lack of moral requirement is, of course, not the same as an ethical prohibition and an ethical examination of the issues is required. It should also be noted that the deaths and injuries as a result of actions carried out to save others will be definite, whereas, deaths and injuries that have not yet occurred are hypothetical and may not occur. It should be noted that there may be analogies between hostage takers who risk harming innocent people to bring about political goals in order to reduce the number of lives lost overall and those who are willing to risk killing innocent hostages to avoid negotiating with 'terrorists' for the same reason [5].

Many, though by no means all of the measures used in the 'war on terror' following the September 11 attacks violated international human rights and humanitarian norms $[50,51]$. The removal of the 'war on terrorism' from the rule of law has led to the erosion of individual rights. This potentially allows any government to label dissidents, national liberation movements and other opponents as 'terrorists' and a 'military threat' in this 'war' [50]. In addition, the 'war on terror' has been marked by discrimination. In particular, several 
Page 9 of 13

thousand Arab nationals and Muslims have been detained in the USA as a form of preventative detention. However, only three of the estimated 5000 non-citizens detained over a period of about two years were charged with offences with any link to terrorism [54].

Thus, the lives of particular minority groups have been made more difficult and individuals have experienced high levels of stress and had their lives disrupted without any gains in terms of combating terrorism. In addition, targeting minority communities leads to discrimination and exclusion and sets back the human rights and antidiscrimination agenda [50]. It also causes antagonism between law enforcement personnel and these communities and makes it extremely unlikely that their members will provide the voluntary assistance necessary to uncover and prevent any real terrorist threat [50]. As discussed in the section on causes and context, tension between different communities, humiliation and the desire for revenge are part of the context which increases the likelihood of terrorist incidents. Thus, in addition to being likely to hinder counter-terrorism activity, the targeting of minorities may actively contribute to increasing the likelihood of terrorist incidents.

Physical integrity rights are a subset of human rights that give protection from extrajudicial murder, disappearance, torture or political imprisonment by the authorities. There is evidence of a linear relationship between the violation of physical integrity rights and an increase in terrorism and that the reduction in terrorism is greatest in countries with the poorest human rights records when there is even a small improvement [55]. Therefore, in addition to its ethically problematical nature, the violation of physical integrity rights by the US government in the 'war against terrorism' is counterproductive with regard to combating terrorism. There are a number of historical examples which show that societies which give up human rights in the interests of security frequently end up with neither [50]. On the contrary it has been suggested that promoting physical integrity rights is the best way to counter terrorism originating overseas [55].

Profile or data screening was developed in the early 1970s in West Germany. It involves searching data for interesting relational features, such as passengers who paid with the same credit card, but travelled separately, and searching on indexing features to locate individuals whose data is in some way similar to that of known potential terrorists. It often involves the use of special software, such as Non-ObviousRelationship Awareness (NORA) [31]. As well as testing for patterns, NORA has access to data from the FBI and the US department responsible for ordering and controlling sanctions against 'rogue' states. This clearly involves violation of the rights to privacy and the presumption of innocence. It also violates the principle of autonomy, since it is carried out without the knowledge of the people being searched, who are therefore not able to object to the violation of privacy. It is also likely to lead to discrimination, with people who are members of particular minority groups, currently Muslims (though this may change), at the greatest risk of being considered suspect, frequently on the basis of very circumstantial evidence. For instance an Egyptian was detained for more than two months on the grounds he had attended a Florida flight school and worked as a mechanic for an airline in Saint Louis [56]. Modern surveillance is increasingly using high technology, such as global positioning systems and biometric identification [57]. Both the use of surveillance technology and data screening give rise to issues of the responsible use of technology as well as the invasion of privacy and violation of civil rights.

\section{Ethics and torture}

Torture violates the absolute prohibition of the 1984 Convention against Torture. It may also violate national law, is unlikely to be effective as a means of obtaining reliable information and may be counterproductive in political terms [53]. In particular the resulting anger and feelings of humiliation and need for revenge may lead to further terrorist attacks and prevent resolution of the underlying problem(s). Torture probably seems particularly morally abhorrent because it functions by degrading and humiliating people, violating their bodily integrity and sense of their own humanity and forcing them to betray their cause by providing information which could be used against it. It is largely utilarian approaches which have been used to justify torture by balancing one person's life and personal integrity against that of large numbers of other people or by permitting lesser evils in emergencies to protect the greater good [58].

This justification generally refers to the so-called 'ticking bomb' terrorist where the apprehended suspected terrorist is believed to have information about a bomb or other terrorist activity which could lead to the deaths of large numbers of people. However, in the one recorded 'ticking bomb' case permission for torture was not given and the bomb did not explode [58]. In another incident a suspected terrorist was tortured and provided information about a plot to blow up 11 aircraft, but this took 67 days and it was probably the fortuitous discovery of documents that foiled the plot [58]. Ethical issues aside, the use of torture in this case was clearly too slow for the resulting information to be useful and was anyway obtained more rapidly by more ethical means. The principle of intervening action is also relevant here, as well as the fact that the discussion is about ethically abhorrent measures to prevent a hypothetical threat about which it is only assumed that the suspected terrorist has knowledge. Even when the correct person has been apprehended and they are in possession of the relevant information it cannot be assumed that any information they give is reliable. This cannot be assumed, since a person being tortured is likely say anything they think will stop the torture and there are many examples of terror suspects giving false confessions under torture [58]. Unless the apprehended terrorist is acting on their own, their colleagues are likely to move the 'ticking bomb' or change the details of the attack once they realise their colleague has been apprehended.

Thus, in a 'ticking bomb' scenario too many conditions need to be met simultaneously for there to be any real likelihood of the use of torture leading to accurate and reliable information in sufficient time for it to be useful. In practice, as indicated above, ticking bomb incidents are very rare and none had been encountered by 2006 in the Iraq war. The use of torture, in circumstances for which there is some justification, very easily leads to its wider user, as happened with the treatment of al-Qaida suspects and in the French occupation and war in Algeria, where torture was initially used exceptionally, but became a 'normal' part of interrogation [58].

Torture can also be seen to violate the major ethical theories. In deontological terms it is wrong, as it violates fundamental principles of humanity. In terms of rule utilarianism the greatest good will be achieved by prohibiting torture, since torture has most frequently been used for bad reasons, including to silence government opponents, so that its prohibition is required to preserve democracy and nonauthoritarian government. In addition, reciprocity means that the prohibition of torture is required to prevent the torture of home soldiers to preserve the lives of 'enemy' forces [58]. With regard to virtue ethics torture is likely to be very psychologically and spiritually damaging to those who participate in or order it and therefore to do 
Page 10 of 13

the opposite of building good character. In terms of the ethics of care situations in which torture take place are likely to be close to the mirror image of those leading to terrorism. They are also characterised by a breakdown of care and relationships across, but not necessarily within communities, a focus on some aspects of the situation, while ignoring its full complexity; and sympathising and empathising with some groups and individuals, but a total lack of awareness of the needs and possibly even the humanity of others. With regard to normative ethics, torture is unjust, does not respect autonomy and causes harm (maleficence) rather than good (beneficence).

It has been suggested that terrorism is a threat to civilization. However, it is rather the destruction of ethical and social values, such as the acceptance of torture, the restriction of civil liberties and human rights and the dehumanization of minority groups, often in reaction to the (fear of) terrorist incidents, which present the greater threat. The use of unethical means to counter terrorism is both likely to destroy the civilization it purports to protect and lead to further terrorist attacks.

\section{Human Rights and the Fear of Terrorism}

\section{The extent of the 'threat'}

Terrorism has been presented as a great threat to civilization, leading to a war on terror and restrictive legislation in a number of countries, including the USA and the UK. It has also sometimes been considered at or close to the summit of moral evils. This poses the questions of whether terrorism is a real threat and how it compares with other moral evils. In terms of 'evil', the following are a few of the 'evils' associated with inadequate development:

- Half the world's population, nearly three million people, lives on less than $\$ 2.50$ a day [59].

- 21,000 children die each day due to poverty [60].

- Nearly a billion people were unable to read a book or sign their names at the start of the twenty-first century [61]

- 72 million children of primary school age, $57 \%$ of them girls, were not even enrolled in school in 2005 [62].

Although there are problems with the consequentialist approach of comparing the numbers of lives lost in different contexts and any death as the result of violence is to be deplored, an examination of the statistics can at least provide information on the seriousness of different threats with regards to the numbers of resulting deaths and injuries. Although any death as a result of violence is to be deeply deplored and the number of terrorism deaths has increased significantly since 2000 to 32,685 in 2014 , this figure is very low compared to other causes of (violent) death:

- 7.67 million deaths of children annually due to poverty [60].

- 1.3 million road deaths annually [63].

- At least 437,000 homicide deaths annually [6].

Thus, though deaths due to terrorism worldwide have increased significantly, they are still only a relatively small number compared to deaths from other causes. However the 3,000 deaths in the September 11 attacks seem to have resulted in much greater fear and grief than the 150,000 deaths in road accidents that occurred in the USA in the following five years [64]. The existence of global climate change due to anthropogenic emissions of greenhouse gases and the resulting threats to food security, biodiversity and low lying areas are generally accepted by scientific opinion $[65,66]$. However a US war against climate change analogous to the war on terror has not been instigated, just as there is no US 'war' on road accidents or poverty, and the USA has not even ratified the Kyoto Convention on Climate Change. While violent deaths should be a matter of concern wherever they occur, in most years there are only a few tens to a few hundred terrorist deaths in western countries. Thus the magnitude and nature of the response to 'terrorism' has been based on perceptions of the extent and nature of the threat rather than the reality. The human rights and civil liberty concerns raised by counter-terrorism measures have already been discussed. The costs of countering terrorism have been estimated at about US\$117 billion, greater than twice the economic costs of terrorism.

In addition, at least part of the costs of terrorism may be due to the fear response and the resulting overreaction rather than the initial terrorist acts [64]. For instance, Russian responses to terrorist acts allegedly committed by the Chechens led to considerably more loss of Russian (and Chechen) lives and property than the original acts. The bombing of a suspect pharmaceutical factory in Sudan by the then US president Clinton in response to the bombing of two American embassies in Africa may have led to the deaths of tens of thousands of Sudanese over time, in comparison to the 200 deaths in the original attacks. The economic costs of increased security and to the tourism industry are many times the direct economic costs of the September 11 attack. Even more significantly, the reaction to this attack has led to much greater loss of lives. For instance, an estimated one hundred thousand Iraqis died in the first eighteen months of the resulting attack on Iraq and the replacement of air by car journeys led to an estimated additional one thousand deaths in car accidents in the three months following September 11 [64].

\section{The nature of the response}

Since the September 11 attacks the 'war on terror' has been presented as the greatest challenge to international security [67]. However, the likelihood of an American being killed in a terrorist attack, on current trends is one in 3.5 million per year, compared to the much higher risks of one in 8,000 of being killed in a car accident and one in 22,000 in a homicide [68]. Various studies show that this gives rise to questions about the reasons for the disproportionate response. It is partly determined by perceptions of the associated risks, with factors affecting the perceived extent and acceptability of different risks including the following [47]:

- The probability, type and severity of the likely consequences. There is often greater concern about dramatic low probability events, such as terrorist attacks than events with a higher statistical risk.

- Whether the risk has been assumed voluntarily and there are associated benefits. The risk of terrorist attacks has not been assumed voluntarily, most people have little control over the risk and any benefits do not accrue to the victims.

- Whether the risk is to known or unknown individuals, with risks to known people generally weighted more highly.

- Whether the consequences are immediate or delayed. In the case of terrorist attacks, the consequences are either immediate or there is uncertainty about when they will occur.

Other factors include the media response, with a significantly increased coverage of terrorism since the September 11 attacks and reports of attacks often slanted to stress fear and anxiety [68]. The security forces also have a vested interest in magnifying the size of the threat in order to continue to receive large budgets to combat it, 
Page 11 of 13

estimated at an increase of $\$ 75$ billion a year since September 2001 [68].

The terrorist threat is generally presented in terms of 'Islamic' terrorism, though the term is misleading, draws on a long history of cultural stereotypes and negative media representations of Muslims and Islam and presents 'Islamic terrorism' as one of the greatest threats to US national security and the western world [69]. However, studies have shown that suicide terrorism has little connection with 'Islamic fundamentalism' or any other world religion [70]. The roles of the threat of 'Islamic terrorism' include building support for and legitimizing US and UK international and domestic policy, including expansion of their military presence into new areas, control of oil, increased resources and power for the military and increased domestic and international surveillance. The labelling of terrorism as religious extremism is used to deliberately conceal its political origins. The 'Islamic terrorism' label also allows the construction of a 'western' identity as liberal and civilised in opposition to the 'backward, violent, illiberal, Islamic "other"' [69].

This relates to scapegoating and the creation of an external enemy [Hersh, 2013] to direct attention away from the real social, political and economic problems affecting the majority of the population even in the wealthiest countries. As well as it being easier to attack and blame the scapegoat than the industrial military complex, the scapegoat can be despised, thereby allowing the majority population to increase their self-esteem and satisfaction with life. The various stereotypes about 'Islamic terrorists' clearly support this. The creation of an external threat can be used to unite people behind the regime, however repressive and otherwise unpopular, and make them accept a range of repressive measures.
Terrorism has the advantage of being able to serve in both the roles of enemy and scapegoat. Since terrorism and terrorists are both seen as an all-pervasive threat and other and outside society, the threat of terrorism can easily be used to justify a range of repressive control measures. Their acceptability is a consequence of a combination of the very real fear of terrorism by many people and the construction of terrorists as other, often in the sense of a dreaded and inhuman enemy. Therefore, these repressive control measures, can be presented as targeting 'them', the terrorists, rather than 'us', the law-abiding citizens, and opposition as being unpatriotic or even as supporting terrorism. Therefore governments can impose very restrictive legislation while maintaining their image of being liberal and freedom loving. This is illustrated in Figure 5, which shows how some of the factors discussed previously give the context for terrorism and violent counter-terrorism. It further illustrates how the threat of terrorist acts is magnified by propaganda and leads to repressive legislation and how this legislation leads to an increase in terrorist acts. This use of propaganda and mythmaking to present terrorists as simultaneously both the dreaded enemy against which society needs to protect itself and the scapegoat responsible for all ills is part of the process of labelling and construction of the other [25]. This enables terrorism both to be considered as an all-pervasive threat against which any measures are justified and as something out there which has not been engendered by the society we are part of [72]. 'We' are neither perpetrators nor victims. In both foreign and internal policy 'a notion of what "we" are ... [is] intrinsic to an understanding of what "we" fear' [72]. This polarization into 'us' and 'them' avoids the need to examine the real underlying issues. In addition any counter-terrorist activity which requires 'terrorists' to be dehumanized or civilian deaths to be trivialised as collateral damage is automatically unjust [73].

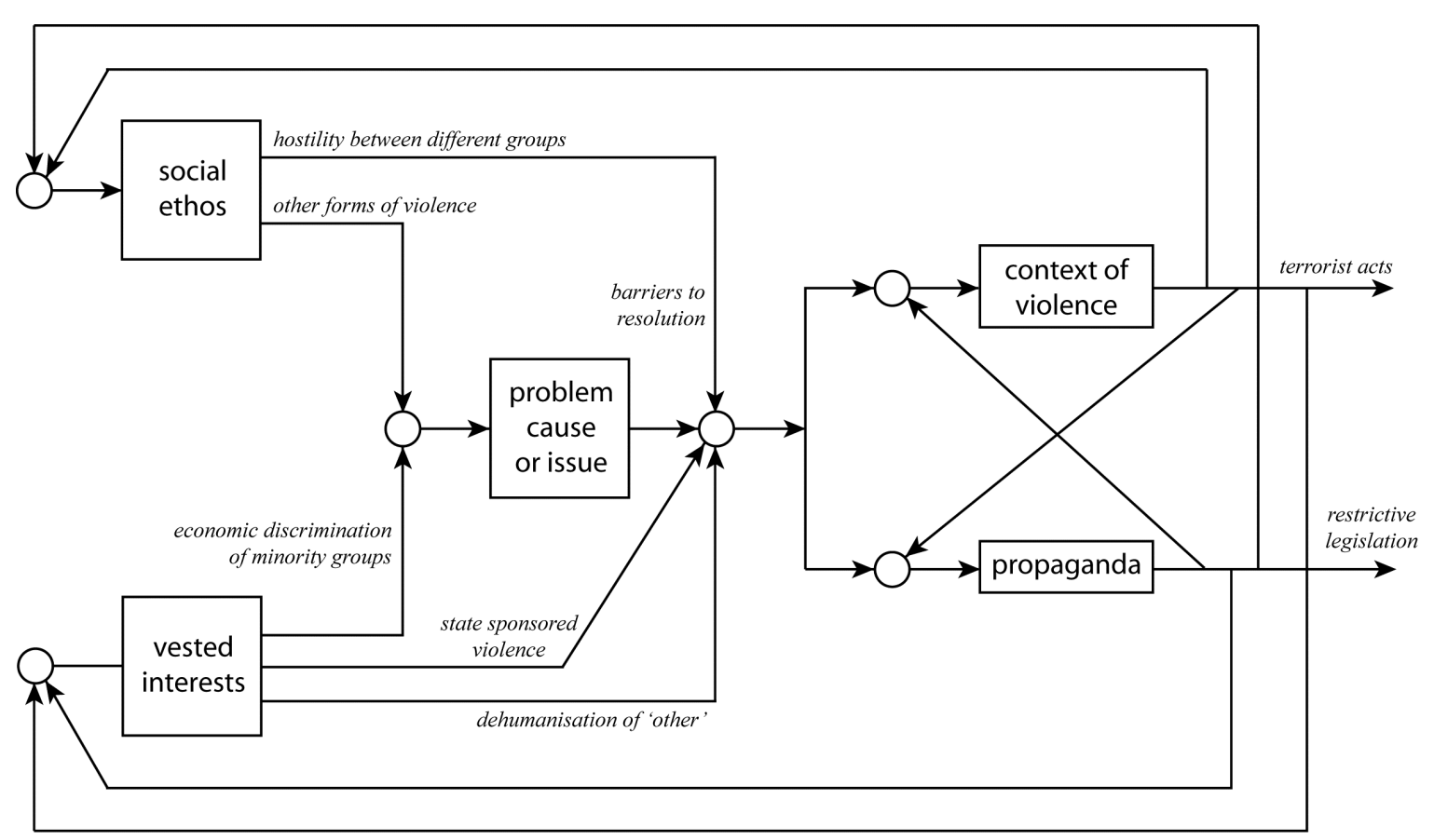

Figure 5: Terrorism and Counter-terrorism 
Page 12 of 13

\section{Conclusions}

The paper has discussed some of the ethical issues associated with terrorism and counter-terrorism. It has presented some of the factors that increase the likelihood of terrorist acts. Consequentialist ethics and just war theory are the approaches most frequently applied to the analysis of terrorism. The paper has also applied a number of other approaches, including rights ethics, virtue ethics, the ethics of care, normative ethics and multi-loop action learning. Virtue ethics has been used to examine the impact of terrorism on the character of the actors involved and the ethics of care the impact on relationships, including changes in power relationships at both the macro and personal levels.

The use of multi-loop action learning [47] has demonstrated that the context that leads to both terrorism and unethical counterterrorism is situated in the wider society and will require changes at that level. This modelling approach has also shown that individuals can influence this wider social and political context, though this is best attempted as part of an organisation. The use of scapegoating and fear by governments has been discussed and the suggestion made that terrorism can be used both as a scapegoat and to promote fear to support policies and actions by governments and vested interests, which are counter to the wishes and interests of the majority of the population. Feedback models have been presented. They include of the relationship between the predisposing context, trigger events and the reaction to terrorism; and the political and social context, terrorism, counter-terrorism and propaganda. The second model has illustrated the way that fear of terrorism has a feedback effect which is used to justify restrictive legislation and that this restrictive legislation has a feedback effect which increases the likelihood of terrorist incidents. In addition, a three component model of the causes of terrorist incidents based on a three component model of the causes of conflict [25] has been presented. The paper has raised a number of questions which still remain to be answered. This will require additional analysis using modelling and ethical analysis tools, as well as further analysis of the relationship between incidents of terrorism and potential causes.

This then raises the issue of the alternatives, in particular how to move beyond the situation where governments need the threat of terrorism to control their own populations and the social and political context supports acts of terrorism. The simple or even simplistic answer would be a total change of perspective, leading to an examination of the causes of the real social and political problems, such as poverty, unequal access to resources and opportunities, discrimination, violation of human rights and famine in a world that produces more than enough food. However, this would require very significant changes in the socio-economic and political system, leading to a reduction in the power of existing elites. It would also require a respect for diversity and difference and an avoidance of the temptation to have power over the 'other' [25]. Unfortunately, this is precisely what many governments, multi-national companies and other vested interests fear and therefore find it preferable to encourage scapegoating and create enemies in order to justify repressive legislation to try and control the population, as well as justify expansionist policies.

\section{Acknowledgements}

I would like to thank Peter McKenna for drawing the figures.

\section{References}

1. http://en.wikipedia.org/wiki/Terrorism
2. Corlett JA (2003) Terrorism: A Philosophical Analysis, Kluwer Academic Publishers, Netherlands 228.

3. Meggle G (2005) Ethics of Terrorism and Counter-Terrorism, Ontos Verlag.

4. Krieger T, Meierrieks D (2011). What causes terrorism?. Public Choice 147: 3-27.

5. Coady CAJ (1986) The idea of violence, J. Applied Philosophy 3: 3-19.

6. Global Terrorism Index (2015) Measuring and understanding the impact of terrorism. Institute for Economics and Peace.

7. Baier AC (1991) Violent demonstrations, Violence, Terrorism and Justice, Cambridge University Press 33-58.

8. Richardson, L. (2006). What terrorists want.

9. Held V (1991) Terrorism, rights and political goals, Violence, Terrorism and Justice, Cambridge University Press 59-85.

10. Ross JI (1993) Structural causes of oppositional political terrorism: Towards a causal model. Journal of Peace Research, 30: 317-329.

11. Primoratz I (2005) State terrorism and counterterrorism, Ethics of Terrorism and Counter-Terrorism, Ontos Verlag 69-82.

12. Narveson J (1991) Terrorism and morality, Violence, Terrorism and Justice, Cambridge University Press 116-169.

13. Lutz JM, Lutz BJ (2004) Global Terrorism, Routledge, UK 382.

14. Kapitan T (2005) 'Terrorism' as a method of terrorism, Ethics of Terrorism and Counter-Terrorism 21-38.

15. Held V (2004) Terrorism and war. The Journal of Ethics 8: 59-75.

16. Messelken D (2005) Terrorism and guerrilla warfare - a comparative essay. Ethics of Terrorism and Counter-Terrorism, Ontos Verlag 51-68.

17. De Calle L, Sánchez-Cuenca I (2012) Rebels without a Territory An Analysis of Nonterritorial Conflicts in the World, 1970-1997. Journal of Conflict Resolution, 56: 580-603.

18. Global Terrorism Index (2014) Measuring and understanding the impact of terrorism. Institute for Economics and Peace.

19. Wallenstein P (2015) Armed conflict overview. SIPRI Yearbook 2012, Armaments, Disarmament and International Security, OUP

20. Kegley CW (1990) International Terrorism, Characteristics, Causes, Controls, St Martin's Press.

21. Piazza JA (2011) Poverty, minority economic discrimination, and domestic terrorism. Journal of Peace Research 48: 339-353.

22. Chenoweth E (2010) Democratic competition and terrorist activity. The Journal of Politics 72: 16-30.

23. Berko, A., \& Erez, E. (2007). Gender, Palestinian women, and terrorism: Women's liberation or oppression?. Studies in Conflict \& Terrorism, 30(6), 493-519.

24. Brison, S. J. (2002). Gender, terrorism, and war. Signs, 28(1), 435-437.

25. Hersh MA (2013). Barriers to Ethical Behaviour and Stability: Stereotyping and Scapegoating as Pretexts for Avoiding Responsibility. Annual Reviews in Control, vol. 37(2), pp. 365-381.

26. Gilbert P (1994) Terrorism, Security and Nationality, An Introductory Study in Applied Political Philosophy, Routledge, UK.

27. Hersh MA (2015). Engineering ethics: defininitions, theories and techniques. In Hersh MA, Ethical Engineering for International Development and Environmental Sustainability, Springer Verlag.

28. Audi R (1971) On the meaning and justification of violence, Violence 75.

29. Hare RM (1984) On terrorism. Assent/Dissent, Kendall/Hunt Publishing Company 247.

30. Wellman C (1979) On terrorism itself, J. Value Inquiry 13: 250-258.

31. Perlo-Freeman S. Solmirano C (2012) The economic cost of the Afghan and the Iraq wars. SIPRI Yearbook 2012, Armaments, Disarmament and International Security, OUP 156-161,

32. Hersh MA (2015) Ethics, scientists, engineers and the military. In Hersh MA ,Ethical Engineering for International Development and Environmental Sustainability, Springer Verlag.

33. https://en.wikipedia.org/wiki/Iraq_War 
34. Laqueur W (1987). The Age of Terrorism, Boston MA: Little, Brown.

35. Coser LA (1966) some social functions of violence, Ann. Am Academy Political and Soc Sci 364: 8-18.

36. Bauhn P (2005) Political terrorism and the rules of just war, Ethics of Terrorism and Counter-Terrorism 123-134.

37. Thompson J (2005) Terrorism, morality and right authority, Ethics of Terrorism and Counter-Terrorism 151-160.

38. Meggle G (2005b) Terror and counter-terror: initial ethical reflections, Ethics of Terrorism and Counter-Terrorism 161-176

39. Burchael JT (1990) Framing a moral response to terrorism, International Terrorism, Characteristics, Causes, Controls, St Martin's Press Inc 213-218.

40. Coady CAJ (2005) Terrorism, just war and right response, Ethics of Terrorism and Counter-Terrorism 135-150.

41. Stremlau J (1998) People in Peril: Human rights, Humanitarian Action and Preventing Deadly Conflict, 25, Carnegie Corp. of New York, USA.

42. Langley C (2006) Scientists or soldiers? Career choice, ethics and the military. Scientists for Global Responsibility.

43. Hill TE (1991) Making exceptions without abandoning the principle: or how a Kantian might think about terrorism 196-229.

44. Smilansky S (2004). Terrorism, Justification, and Illusion. Ethics, 114(4), 790-805.

45. Salt of Earth (2000) http://salt.claretianpubs.org/ stats/2000/04/ sh0004.html.

46. Oakley J (1998) A virtue ethics approach, A Companion to Bioethics 86-97.

47. Hersh MA (2006) Mathematical Modelling for Sustainable Development, Springer Verlag, ISBN 3-540-24216-3.

48. Nielson RP (1996) The Politics of Ethics, Oxford University Press, USA.

49. Hersh MA (2004) Whistleblowers - heroes or traitors? individual and collective responsibility for ethical behaviour, Annual Reviews in Control 26: 243-262.

50. Hoffman P (2004) Human rights and terrorism. Human Rights Quarterly 26: 932-955.

51. Amnesty International (2002) Rights at Risk: Amnesty International's Concerns regarding Security Legislation and Law Enforcement Measures. AI-ACT--30/001/2002.

52. Weisburd D, Jonathan T, Perry S (2009) The Israeli model for policing terrorism goals, strategies, and open questions. Criminal Justice and behavior 36:1259-1278.

53. Khatchadourian H (2005) Counter-terrorism: torture and assassination, Ethics of Terrorism and Counter-Terrorism 177-196.
54. Cole D (2003) Enemy aliens: Double standards and constitutional freedoms in the war on terror. Current Affairs.

55. Walsh JI, Piazza JA (2010) Why respecting physical integrity rights reduces terrorism. Comparative Political Studies.

56. Groetker R (2005) Looking for Mohammed: data screening in search of terrorists, Ethics of Terrorism and Counter-Terrorism 301-318.

57. Bewley, Taylor DR (2005) US concept wars, civil liberties and the technologies of fortification, Crime, Law and Social Change 43: 81-111.

58. Bellamy AJ (2006) No pain, no gain? Torture and ethics in the war on terror, Int. Affairs 82: 121-148.

59. Shah A (2013) Poverty facts and stats.

60. Shah, A. (2011). Today, around 21,000 children died around the world.

61. UNICEF (1999). The state of the world's children

62. Anon (2007a). Millenium Development Goals Report. United Nations Department of Economic and Social Affairs DESA, ISBN 97 8-9 2-1-101-153-1.

63. http://www.transpoco.com/blog/2014/12/16/road-safety-1-3-millionroad-fatalities-happen-every-year/http://www.transpoco.com/blog/ 2014/12/16/road-safety-1-3-million-road-fatalities-happen-every-year/

64. Mueller, John (2005) Six Rather Unusual Propositions About Terrorism, Terrorism and Political Violence 17: 487-505.

65. Houghton JT (2001) Climate Change 2001: Scientific Basis

66. Intergovernmental Panel on Climate Change (IPCC), 2014, Climate Change, Fifth Assessment Report, Working Group II, Impacts, Adaptation and Vulnerability, Summary for Policymakers.

67. Heng YK (2002) Unravelling theWar'on Terrorism: A Risk-Management Exercise in War Clothing?. Security Dialogue, 33: 227-242.

68. Mueller J,Stewart MG (2012) The terrorism delusion: America's overwrought response to September 11. International Security 37: 81-110.

69. Jackson R (2007) Constructing enemies:'Islamic terrorism'in political and academic discourse. Government and Opposition 42: 394-426.

70. Pape R (2005) Dying to Win: The Strategic Logic of Suicide Terrorism, New York, Random House 4.

71. Dutta N (2004) The face of the other, terror and the return of binarism. Interventions 6: 431-450.

72. Campbell D (1998) Writing Security: United States Foreign Policy and the Politics of Identity, Manchester University Press 3: 73.

73. Termes P (2003) The Just War: an American Reflection on the Morality of War in Our Time, Chicago,USA 149: 179. 